\title{
Atuação e funcionamento da Justiça no Brasil Imperial: o caso do Tribunal do Júri de São Leopoldo/RS
}

Caroline von Mühlen*

Resumo: Temos neste artigo, como objetivo central, analisar como a Justiça institucional foi aplicada no interior da Província do Rio Grande do Sul, atentando para o processo de instalação e funcionamento do Tribunal do Júri de São Leopoldo. Embora exista um número crescente de trabalhos nos últimos anos, acerca do estudo da Justiça oficial e de seus agentes no cenário nacional e regional, ainda carecemos de estudos acerca da Justiça oficial local e, especialmente, análises comparativas que contemplem as práticas de justiça não oficiais existentes nas colônias. A partir de fontes diversas, encontradas no Memorial do Judiciário, no Arquivo Histórico do Rio Grande do Sul, no Arquivo Público do Rio Grande do Sul e em outros arquivos, buscamos promover uma reflexão sobre a Justiça em São Leopoldo, na segunda metade do século XIX. Para alcançar este objetivo, metodologicamente, analisaremos as fontes de forma quantitativa e qualitativa, além de promover o cruzamento das mesmas, com intuito de encontrar indícios sobre o Tribunal do Júri, os jurados, os réus e as vítimas.

Palavras-chave: Tribunal do Júri. São Leopoldo. Século XIX.

\footnotetext{
"Doutora em História pela Pontifícia Universidade Católica do Rio Grande do Sul - PUCRS. Essa pesquisa foi financiada pelo Conselho Nacional de Desenvolvimento Científico e Tecnológico - CNPq. E-mail: carolinevm7@gmail.com.
} 
Atuação e funcionamento da Justiça no Brasil Imperial: o caso...

\section{Introdução}

Sobre a origem do Tribunal do Júri, não há um consenso entre os estudiosos. Os mais liberais acreditam que a sua existência remonta à época mosaica, isto é, entre os hebreus a.C., e até entre os gregos e romanos existiu uma estrutura que julgava pelos pares e em nome de Deus. Outros, contudo, definidos como conceitualistas, identificam o surgimento do Júri à época do Concílio de Latrão, tendo a Inglaterra como berço. A maior parte dos juristas, entretanto, concorda que a verdadeira origem do Tribunal do Júri, na forma em que o conhecemos atualmente, deu-se em 1215, na Inglaterra, quando o Concílio de Latrão aboliu os Juízes de Deus e instalou o Conselho de Jurados.

Assim, por volta do século XII, à época do Common Law, o rei Henrique II, da Normandia, criou o Grand Jury, composto por doze homens juramentados, que tinha a função de denunciar aquela pessoa que cometesse algum crime ou infração, além de determinar se houve ou não um crime. Aos poucos, os julgamentos supersticiosos ou nos quais Deus interferia nas decisões, davam lugar a testemunhas de fato mais conscientes e responsáveis pelo julgamento do criminoso. Essas mudanças difundiram-se no mundo e passaram a ser adotadas por vários países, como na Alemanha, onde o Júri foi instalado por volta de 1830; a França implantou um Júri de acusação e Júri de julgamento, e nos Estados Unidos a instalação do Tribunal do Júri ocorreu somente após a independência das colônias norte-americanas.

No Brasil, em 1820, já existia um tribunal responsável pelo julgamento dos delitos de imprensa, sendo composto por vinte e quatro cidadãos, "homens bons, honrados, inteligentes e patriotas, os quais serão os Juízes de Fato, para conhecerem da criminalidade dos inscritos abusivos", e serão "[...] nomeados pelo Corregedor do Crime da Corte e Casa, pelo Ouvidor do Crime nas Províncias que tiverem Relação, ou, nas demais, pelo Juiz da Comarca”. É interessante destacar que os réus "[...] podiam recusar dezesseis dos vinte e quatro: os oito restantes seriam suficientes para compor o Conselho de Julgamento - acomodando-se sempre às formas mais liberais e admitindo-se o réu à justa defesa" (NEQUETE, 2000, p. 29). 
O Decreto de dezoito de junho de 1822 "[...] foi idealizado para assegurar as garantias mínimas de defesa para aquele que será julgado por seus pares pelo fato criminoso que cometeu, ou seja, será julgado por pessoas iguais a ele, pessoas comuns da comunidade em que ele vive" (CARVALHO, 2009, p. 95). Esse decreto criou o Tribunal dos "Juízes de Fato", que era constituído por cidadãos comuns com a incumbência de exercerem a atividade jurisdicional, como bem lembra José Murilo de Carvalho. Contudo, criar uma nova instância criminal responsável pela administração da Justiça no Brasil foi uma das medidas descentralizadoras executadas pelos liberais durante o Primeiro Reinado. Criou-se uma grande expectativa em torno dessa nova instituição, pois acreditavam que ao definir a forma e as competências do Tribunal do Júri, a justiça brasileira melhoraria. "Sua função na justiça criminal e cível veio a se destacar, primeiramente, com a Constituição de 1824, ainda que só teoricamente, e depois com o Código Criminal de 1830" (BETZEL, 2009, p. 95).

O Tribunal do Júri era um órgão local formado por um Conselho ocupado por pessoas da própria comunidade e presidido pelo Juiz de Direito, ou seja, foi criado para que a comunidade de determinado lugar "[...] julgasse os fatos cometidos pelo que era aceitável ou não para aqueles que iriam continuar a conviver [...]" com o réu que havia desrespeitado a lei. Dessa forma, o réu não era julgado por um Juiz Togado, mas por "pessoas idôneas da cidade em que foi cometido o crime, que decidirão se o fato praticado [...] deve ser punido com o recolhimento ao cárcere ou não" (CARVALHO, 2009, p. 95).

A Constituição Imperial de 1824 incluía o Tribunal do Júri como órgão integrante do Poder Judiciário, passando a julgar causas cíveis e criminais. No título VI, "Do poder judicial”, da Constituição, ficou determinado que fosse "[...] independente e será composto por Juízes e Jurados [...]" (Art. 151), e os "[...] jurados pronunciam sobre o fato e os Juízes aplicam a lei” (Art. 152). Contudo, a legislação foi alterada inúmeras vezes, modificando assim a competência do Tribunal do Júri.

A primeira modificação ocorreu com a aprovação da Lei de dezesseis de dezembro de 1830, quando se introduziram dois 
Atuação e funcionamento da Justiça no Brasil Imperial: o caso...

tribunais: o de acusação e o de julgamentos. Cabia aos jurados do primeiro Tribunal decidir se o processo seria aceito ou não. Sendo aceito, o processo passava pelo Tribunal de Julgamento.

O Código de Processo Criminal de 1832 ampliou a competência do Júri determinado, até então, pela Lei de vinte de setembro de 1830. A substituição dos Livros I e III das Ordenações por uma nova organização judiciária foi a grande novidade instituída, pois sua competência ia muito além dos casos de liberdade de imprensa. Os crimes e as contravenções com penas menos rigorosas, multa de até cem mil réis, degredo ou desterro de até seis meses, prisão, pena de três meses nas oficinas públicas ou casa de correção, eram julgados pelos Juízes de Paz, enquanto os demais crimes eram de competência do Júri. Dessa forma, as províncias eram divididas em Comarcas, Termos e Paróquias; e em cada Termo deveria existir um Conselho de Jurados, cuja sessão era presidida pelo Juiz de Direito.

O Código de 1832 manteve os dois conselhos de jurados: o conselho de acusação, que "[...] decidia se havia matéria para acusação, ou seja, confirmava que no processo contavam elementos esclarecedores sobre o crime e sua autoria [...]”, e o conselho de sentença, quando "[...] depois de acusado, o réu respondia diretamente perante outro conselho, o júri de sentença” (FERREIRA, 2007, p. 4).

Em cada Termo, pertencente a determinada Comarca, organizava-se uma lista de jurados. De acordo com o Código do Processo Criminal, podia ser jurado aquele que pudesse ser eleitor, ou seja, "[...] são aptos para serem jurados todos os cidadãos que podem ser eleitores, sendo de reconhecido bom senso e probidade" (Art. 23). A participação popular, como jurados, na administração da Justiça "[...] possuía a implicação de conferir legitimidade ao exercício do poder de julgar e punir do Estado" (FIGUEIRA, 2014, p. 3). De acordo com José Murilo de Carvalho (2013, p. 29-30),

[...] a Constituição regulou os direitos políticos, definiu quem teria direito de votar e ser votado. Para os padrões da época, a legislação brasileira era muito liberal. Podiam votar todos os homens de 25 anos ou mais que tivessem renda mínima de 100 mil-réis. Todos os cidadãos qualificados eram obrigados a votar. As mulheres não votavam, e os 
escravos, naturalmente não eram considerados cidadãos. Os libertos podiam votar na eleição primária. A limitação de idade comportava exceções. O limite caía para 21 anos no caso dos chefes de família, dos oficiais militares, bacharéis, clérigos, empregados públicos, em geral de todos os que tivessem independência econômica. A limitação de renda era de pouca importância. A maioria da população trabalhadora ganhava mais de 100 mil-réis por ano. Em 1876, o menor salário do serviço público era de 600 mil-réis. O critério de renda não excluía a população pobre do direito do voto. Dados de um município do interior da província de Minas Gerais, de 1876, mostram que os proprietários rurais representavam apenas $24 \%$ dos votantes. O restante era composto de trabalhadores rurais, artesãos, empregados públicos e alguns poucos profissionais liberais. As exigências de renda na Inglaterra, na época, eram muito mais altas, mesmo depois da reforma de 1832. A lei brasileira permitia ainda que os analfabetos votassem. Talvez nenhum país europeu da época tivesse legislação tão liberal. [...] Esta legislação permaneceu quase sem alteração até 1881 .

A lista com o nome dos cidadãos aptos, bem como a revisão da mesma, era realizada “[...] em cada Distrito por uma Junta composta por um Juiz de Paz, Pároco ou Capelão e o Presidente ou algum dos Vereadores da Câmara Municipal respectiva ou na falta destes últimos, um homem bom, nomeado pelos dois membros da Junta que estiverem presentes" (Art. 24). Nesse contexto, o Juiz de Paz tornou-se uma figura importante na administração da Justiça. Além de atribuições policiais e judiciais, o Juiz de Paz podia participar da elaboração da lista dos jurados, e também "[...] competia-lhe entre outras coisas: 1) os procedimentos relativos à formação de culpa; 2) prender os culpados; 3) julgar os crimes de menor importância" (FIGUEIRA, 2014, p. 7). Depois de feita a lista, "[...] serão afixadas à porta da Paróquia ou Capela e publicadas pela imprensa em os lugares em que haja e se remeterão às Câmaras Municipais” (Art. 25).

Após quinze dias da revisão da lista e afixada na porta da Câmara Municipal, deve-se "[...] transcrever os nomes dos alistados 
Atuação e funcionamento da Justiça no Brasil Imperial: o caso...

em pequenas cédulas, todas de igual tamanho" (Art. 30), e no dia seguinte lia-se os nomes dos jurados sorteados. Com a Reforma de 1841, os jurados aptos continuavam sendo os cidadãos eleitores, porém o rendimento anual foi elevado de duzentos mil réis para quatrocentos mil réis "nos Termos das Cidades do Rio de Janeiro, Bahia, Recife e S. Luiz do Maranhão: trezentos mil réis nos Termos das outras Cidades do Império; e duzentos em todos os mais Termos [...]” (Art. 27), bem como a exigência de saber ler e escrever.

A Reforma de 1841 não modificou somente o valor da renda anual dos cidadãos aptos para serem jurados, mas também a competência de quem deveria realizar tal procedimento. Passava a ser incumbência dos delegados de polícia organizar uma lista "[...] de todos os cidadãos, que tiverem as qualidades exigidas no artigo antecedente, e a farão afixar na porta da Paróquia, ou Capela, e publicar pela imprensa, onde a houver [...]” (Art. 28), e não mais dos Juízes de Paz, que passaram a ser confundidos como suplentes de delegado. Depois de pronta, as listas eram "[...] enviadas ao Juiz de Direito, o qual com o Promotor Público, e o Presidente da Câmara Municipal formará uma Junta de revisão [...]”, com o objetivo de excluir os

[...] indivíduos que notoriamente forem conceituados de fatos de bom senso, integridade, e bons costumes, os que estiverem pronunciados, e os que tiverem sofrido alguma condenação passada em julgado por crime de homicídio, furto, roubo, bancarrota, estelionato, falsidade ou moeda falsa (Art. 29).

Verifica-se aqui a tentativa de reduzir a participação e influência das elites locais, bem como reduzir a participação dos cidadãos brasileiros na administração da Justiça. Além do Juiz de Direito, a Coroa passou a nomear também os Promotores e Juízes Municipais, centralizando assim o poder nas mãos do Imperador. Outra mudança foi a extinção do Júri de acusação, "[...] que tinha a incumbência de dar uma decisão judicial que enviava - ou não - o réu para julgamento pelo Júri de sentença [...]” (FIGUEIRA, 2014, p. 13), mantendo somente o Júri de sentença, visando assim a fortalecer 
a figura do juiz e da autoridade policial, uma vez que a atribuição de decisão de pronúncia "[...] ficou a cargo do chefe de polícia, dos juízes municipais, dos delegados e subdelegados de polícia” (Art. 54).

A reforma propôs a separação entre a polícia e a justiça, isto é, a fase investigativa do processo ficava sob a responsabilidade do delegado. Este deveria juntar todas as provas e informações para formar a culpa do réu. A formação de culpa, que anteriormente era incumbência dos Juízes de Paz, consistia na investigação dos fatos, auto de corpo de delito, interrogatório, inquirição das testemunhas e indicação do culpado, e passou a ser tarefa do Chefe de Polícia e dos Delegados. Concluída a formação de culpa, o Delegado remetia os autos conclusos do processo ao Juiz Municipal, que, por sua vez, seria apreciado pelo Júri para julgar o processo condenando ou absolvendo o réu.

Vimos até aqui as determinações que o Código do Processo Criminal de 1832 e a sua Reforma de 1841 propunham quanto aos procedimentos que cada Tribunal do Júri do Império Brasileiro deveria seguir tanto em âmbito nacional quanto regional e local. Além da análise da legislação vigente à época, o francês Pierre Bourdieu (2002, p. 17) lembra que o campo jurídico "[...] deve ser pensado também como um espaço social". O mesmo autor enfatiza que "[...] as práticas e discursos resultam das relações específicas que o estruturam, orientando as lutas pela concorrência e pela lógica interna das obras que delimitam o universo das soluções propriamente jurídicas”. Pensando o campo jurídico tal qual apresentou Bourdieu e através de uma análise qualitativa, quantitativa e do cruzamento de fontes diversas, objetivamos entender qual era a estrutura, a função e a atuação do Tribunal do Júri de São Leopoldo, se a instituição jurídica enfrentou dificuldades para se organizar, quem ocupava a função de Jurados e se os jurados de fato compareciam às sessões que ocorriam anualmente.

Concordamos com Carlos Bacellar (2011, p. 44, grifos do autor), quando diz que "[...] o historiador que se aventura nos arquivos, de qualquer época, deveria ter preocupações em conhecer o funcionamento da máquina administrativa para o período que pretende pesquisar”. Diante do exposto, conhecer a legislação que definia os crimes e as punições permite ao pesquisador compreender a 
Atuação e funcionamento da Justiça no Brasil Imperial: o caso...

estrutura de um processo, a forma como era conduzida pelas autoridades, quais os personagens envolvidos e entender a concepção de Justiça da época.

\section{O caso de agressão envolvendo os colonos Carlos Trott e José Ness ${ }^{2}$}

Em 1866, o colono José Ness, residente na Capela da Piedade, 4o distrito de São Leopoldo, alegou ter sido agredido com um pau por Carlos Trott. A desavença resultou em inúmeras contusões e ferimentos pelo corpo, conforme atestou o exame de corpo de delito realizado na vítima dois dias após o ocorrido. Pela Reforma do Código do Processo Criminal, qualquer pessoa podia representar uma queixa ou denúncia, cuja parte autora do processo seria a Justiça, através do Promotor Público. Aceita a denúncia, instaurou-se um sumário de culpa ex officio contra Carlos Trott para verificar a veracidade das informações e circunstâncias dos fatos. É importante destacar que o processo iniciava com uma queixa, com o sumário de culpa ou por intermédio do oficial da justiça, geralmente de forma ex officio. ${ }^{3}$ A formação de culpa, pela Reforma de 1841, competia aos Delegados e Subdelegados. A primeira tarefa era investigar os fatos e realizar o exame de corpo de delito, no qual os peritos responsáveis, geralmente, eram pessoas da própria comunidade. Foram peritos no processo envolvendo Carlos Trott os senhores Justiniano de Castro e Jacob Altmeyer, ambos residentes na Capela da Piedade, no $4^{\underline{a}}$ distrito de São Leopoldo. Eles juraram perante o Juiz "bem e fielmente desempenharem sua missão declarando com verdade o que descobrissem e encontrassem e o que em suas consciências entenderem", respondendo a dez quesitos.

Após avaliar a vítima, constataram que ela apresentava ferimentos na região frontal, ferimentos e contusões nos braços e em outras partes do corpo. Os ferimentos foram feitos por um instrumento contundente, provavelmente um pau, conforme alegou a vítima no processo. Realizado o exame de auto de corpo de delito, o réu foi interrogado ou qualificado. Por fim, as testemunhas foram "[...] 
obrigadas a comparecer no lugar, e tempo, que lhes foi marcado; não podendo eximir-se desta obrigação por privilégio algum" (Art. 85). Definida a hora e o local para serem interrogadas, "[...] as testemunhas devem ser juramentadas conforme a Religião de cada uma", e depois "[...] devem declarar seus nomes, prenomes, idades, profissões, estado, domicílio ou residência, se são parentes, em que grau, amigo, inimigo ou dependentes de alguma das partes; bem como o mais que lhe for perguntado sobre o objeto" (Art. 86). Nos casos de denúncia, podiam ser inquiridas de cinco a oito testemunhas. Quando, no processo, houver mais de um réu e as testemunhas não depuserem contra ambos, o Juiz poderia inquirir mais duas ou três testemunhas. ${ }^{4}$ Assim que o Delegado e Subdelegado do distrito tivessem juntado todas as partes necessárias para a formação de culpa do réu, os autos conclusos eram enviados ao Juiz Municipal "[...] para sustentar ou revogar a pronúncia ou despronúncia; no caso de não pronúncia e de estar o réu preso, não será solto antes da decisão do Juiz Municipal” (Art. 49). Contendo todas as peças, conforme determinava o Código do Processo Criminal, e pronunciado o réu pelo Juiz Municipal, os autos seguiam para apreciação pelo Tribunal do Júri.

Assim, após a conclusão de todos os procedimentos previstos na lei, o processo criminal envolvendo o réu Carlos Trott foi encaminhado ao Tribunal do Júri, que, por sua vez, daria início ao julgamento com o processo corretamente preparado e após as partes serem devidamente informadas acerca do dia, hora e local da sessão. O Subdelegado do $4^{\underline{a}}$ distrito de São Leopoldo, Valentim Geyer (grifos nossos), informou:

[...] julgo procedente o procedimento ex ofício contra o réu Carlos Trott em face do corpo de delito [...] e depoimentos contestes dos quatro informantes [...] e portanto o pronuncio incurso no artigo 205 do Código Criminal [...] e remeto este processo ao Dr. Juiz Municipal do Termo.

Acerca do local designado para o funcionamento da Câmara Municipal, para a realização das sessões do Júri e para recolher os presos, constatamos que frequentemente mudava de lugar, visto 
Atuação e funcionamento da Justiça no Brasil Imperial: o caso...

que o município não possuía prédio próprio, alugando assim casas de membros da comunidade local. Em 1854, por exemplo, Júlio Henrique Knorr,

[...] em conformidade de um edital publicado nesta Vila por ordem, tenho a honra de oferecer a minha casa sita na Rua do Passo com todas as comodidades necessárias para celebrar as sessões do Júri e das audiências para os diferentes juizados por 320 réis por ano, não sendo este contrato por menos de um ano. ${ }^{5}$

Quando a Lei $\mathrm{n}^{\mathrm{o}}$ 4, de primeiro de abril de 1846, elevou a Capela Curada a Vila, "[...] a Câmara ainda não estava aparelhada" (MOEHLECKE, 2011, p. 37). Após constantes mudanças, somente em 1886 '“...] disseram os vereadores: 'o edifício que se acha em construção, acha-se quase concluído, tanto que no dia $1^{\underline{a}}$ do próximo mês, funcionarão nela suas sessões"' (MOEHLECKE, 2011, p. 71).

Posteriormente, com a sessão do Júri marcada para o dia quatro de junho daquele ano, pelas dez horas da manhã, realizou-se o sorteio das quarenta e oito pessoas que poderiam atuar como jurados "[...] que tem de servir na mesma sessão". ${ }^{6}$ Como na maioria das vezes não se alcançava o número mínimo de cinquenta pessoas habilitadas para a composição do Júri, reuniam-se as pessoas qualificadas dos Termos mais próximos para atingir a marca legal. No Termo de São Leopoldo, local onde ocorriam sessões do Júri, constatamos que tal procedimento era comum. Dessa forma, foram designados dezesseis cidadãos da Freguesia de São Leopoldo, dois da Freguesia de São Miguel, dezoito da Freguesia de Santa Anna do Rio dos Sinos, oito da Freguesia de Santa Cristina e quatro da Freguesia São José do Hortêncio "[...] para comparecer na Casa da Câmara Municipal, em sala das Sessões do Júri" ${ }^{7}$ Realizou-se a chamada dos jurados, verificando se os quarenta e oito cidadãos designados se encontravam presentes e se havia quarenta e oito cédulas com os nomes das pessoas que podiam servir como jurados nas urnas. "Imediatamente eu Escrivão, abaixo nomeado [...] averiguou-se estarem presentes trinta e oito jurados, pelo que o Juiz de Direito passando a tomar conhecimento das faltas e escusas dos jurados que tinham 
deixado de comparecer, anunciou as multas que impusera". ${ }^{8} \mathrm{Ou}$ seja, os cidadãos qualificados como jurados que não compareciam às sessões eram multados.

Após a verificação das pessoas habilitadas e das cédulas, as partes (réu, vítima e testemunhas) eram chamadas para realizar o juramento. Nessa ocasião, foi nomeado João Daniel Krüger como intérprete do réu. Posteriormente, foram sorteados os doze "[...] juízes de fato que tinham de formar o Júri de sentença”. Cabia a um menor (André Miguel dos Santos Júnior) "[...] que tirasse as cédulas cada uma por sua vez [...]" com os nomes. Entretanto, as partes tinham o direito de recusar as pessoas que considerassem perigosas ao processo de defesa ou acusação. O réu Carlos Trott recusou inúmeras pessoas, "[...] e por que se esgotasse a urna das quarenta e oito cédulas sem que se pudesse preencher o número dos doze [...] Juízes de fato para compor o Júri de sentença em consequência de serem recusados", o julgamento foi adiado. Constatamos que o não comparecimento no dia das sessões do Júri era mais comum e frequente entre jurados de São Leopoldo do que imaginávamos. Enquanto alguns cidadãos qualificados como jurados não justificavam sua ausência, outros geralmente não compareciam motivados por algum tipo de doença (MHVSL, documentos diversos, 1846-1871). Percebe-se, assim, que mesmo havendo multa, o número de ausências foi recorrente no século XIX. Vejamos os exemplos a seguir.

Em 1850, Francisco da Silva Maia foi multado em sessenta mil réis por não ter participado em três dias das seções do Tribunal do Júri. ${ }^{10}$ Na seção do dia 23 de agosto de 1858, o Juiz de Direito anunciou que "[...] multará na quantia de 10 mil réis a cada um [...]" dos cinco jurados "[...] por terem faltado à sessão sem causa justificada”. ${ }^{11}$ Em 23 de abril de 1869, o escrivão Luís José de Sampaio anotou no Livro de Multas o termo "[...] das multas impostas aos Jurados, que deixarem de comparecer sem escusa legítima às sessões deste Termo [...]”, pelo Juiz de Direito da $2^{\circ}$ Vara Crime, Manoel José de Freitas Travassos Filho. Nessa ocasião, o Juiz de Direito havia imposto as seguintes multas aos jurados:

[...] Cristiano Sauer, José Martins Pires, José Henrique a quantia de oitenta mil réis a cada um por terem faltado 
Atuação e funcionamento da Justiça no Brasil Imperial: o caso...

sem participação alguma a todas as quatro reuniões da presente sessão, sendo na razão de vinte mil réis a multa imposta a cada um dos ditos jurados por cada dia que deixaram de comparecer; aos jurados Manoel de Azevedo Barbosa, Jacob Dietrich, João Cristiano Fischer, Agostinho de Souza, Loureiro Antônio Marcelino Nunes, Francisco Antônio Medina, Francisco Alves dos Santos na quantia de quarenta mil réis a cada um por terem faltado sem escusa legítima as quatro reuniões desta sessão, sendo-lhes imposta a multa na razão de dez mil réis a cada um em todos os dias que igualmente deixaram de comparecer. E finalmente ao jurado José Straatmann, sendo-lhe imposta a multa na razão de dez mil réis por cada dia de falta. ${ }^{12}$

As sessões do Júri em São Leopoldo ocorriam a cada seis meses, e para compor o número de jurados podia-se reunir mais de um termo, conforme determinava a lei; todavia, a ausência do número exigido por sessão contribuía para tornar o julgamento moroso. Além da ausência de pessoas habilitadas como Juízes de Fato, outro problema verificado por pesquisadores foi o adiamento das reuniões do Júri devido à falta de processos corretamente instruídos. Tais problemas contribuíram para que o Tribunal do Júri ficasse conhecido pela sua inoperância no combate da criminalidade. Vimos que a sessão que julgaria o réu Carlos Trott no dia quatro de junho foi cancelada. Novo julgamento foi marcado para o dia cinco de novembro do mesmo ano. Novamente, foram escolhidos doze jurados e procedeu-se o juramento de imparcialidade em relação ao réu, sobre os Evangelhos. As partes apresentavam-se para a realização do auto de qualificação, seguido por um interrogatório tanto do réu quanto das testemunhas. Após o interrogatório, “[...] a palavra era concedida, primeiramente, à acusação, o Promotor e, em seguida, à defesa, podendo gerar réplica e, até, tréplica” (BETZEL, 2006, p. 90). Depois, cabia ao Juiz resumir o assunto, para que os "Juízes de Fato" pudessem responder aos quesitos numa sala secreta.

Numa sala reservada, secretamente, os jurados analisaram e julgaram os quesitos contra o réu Carlos Trott. Após tal procedimento, voltavam para a sala de sessões, o Presidente do Júri 
respondia aos quesitos e anunciava o número de votos para cada uma das perguntas. Foi respondido pelos jurados somente o primeiro quesito, negativamente, e "[...] deixa[m] de responder os mais quesitos por julgá-los prejudicados [...]"13, isso porque se negou a existência do delito. Logo, as outras questões perderam sentido. Nos autos criminais analisados em São Leopoldo, nem sempre todos os quesitos elaborados pelo magistrado eram respondidos. Às vezes deixavam de responder um quesito, dois ou mais, de acordo com a análise dos mesmos. O Juiz de Direito, "[...] em conformidade da decisão do Júri absolvendo o réu Carlos Trott da acusação que lhe foi intentada [...]"14, também podia noticiar sua apelação ao Tribunal da Relação no Rio de Janeiro. Nesse sentido, apesar de absolvido pelos jurados, o Juiz de Direito Luis José de Sampaio apelou da "[...] decisão do Júri proferida em favor do réu [...]", ${ }^{15}$ o qual foi novamente absolvido, prolongando assim o intervalo entre a data que ocorreu o delito, a prisão do suspeito e o julgamento do mesmo.

A apelação podia ocorrer após o julgamento pelo Tribunal do Júri e seu pedido podia ser feito pelo Juiz de Direito, pelo Promotor, pelo réu ou seu defensor. Além disso, esse recurso poderia ser direcionado para o Juiz de Direito da Comarca ou, ainda, para o Tribunal da Relação no Rio de Janeiro. Viviani Betzel lembra que o direito de apelar da decisão podia tornar o processo mais demorado, principalmente naqueles locais onde as sessões ocorriam de seis em seis meses. Dos 107 autos criminais levados ao Tribunal do Júri de São Leopoldo, entre 1846 e 1871, encontramos apenas vinte apelações, sendo o maior número entre 1861 e 1871 (ver tabela 1). Possivelmente, tal dado aponta para a frustração dos magistrados em saber que a sentença do réu seria a mesma da decisão anterior. Quando recorria-se a tal benefício, cabia às autoridades fazer uma cópia do processo que deveria permanecer no Cartório, “[...] para o julgamento da apelação só subirá o processo original quando nele não houverem mais réus para serem julgados, aliás subirá traslados” (Art. 85). 
Atuação e funcionamento da Justiça no Brasil Imperial: o caso...

\section{Tabela 1 - Apelações computadas no Termo de São Leopoldo (1846-1871)}

\begin{tabular}{c|c}
\hline Ano & Incidência de apelações \\
\hline $1846-1850$ & 12 processos e 1 apelação \\
\hline $1851-1860$ & 27 processos e 2 apelações \\
\hline $1861-1871$ & 68 processos e 17 apelações \\
\hline Total & 107 processos e 20 apelações \\
\hline
\end{tabular}

Fonte: Elaborado pela autora com base em: APERS, processos criminais, 1846-1871.

O processo envolvendo o réu Carlos Trott e a vítima José Ness não foi utilizado por acaso neste texto. Optamos por esse caso, uma vez que o processo apresenta uma letra legível do início ao fim, está completo e sem rasuras, apresenta todas as etapas exigidas pela Justiça e por envolver personagens de origem alemã, visando a desmitificar a ideia de que eram "pacíficos". Todavia, esse e os demais processos, bem como o cruzamento com outras fontes, permitem tecer algumas considerações. Constatamos que o Júri iniciou a sua organização após o dia primeiro de abril de 1846, ano em que a Colônia Alemã de São Leopoldo foi elevada à condição de Vila. É importante lembrar que, mesmo deixando de ser Freguesia, São Leopoldo ainda pertencia à Comarca de Porto Alegre, sob a definição de Termo, visto que a administração judiciária nas Províncias do Império era distribuída em Comarcas, Termos e Paróquias.

De acordo com o Livro de Atas da sessão do Tribunal do Júri, a primeira sessão foi realizada no dia quinze de dezembro de 1846, no Passo da Câmara Municipal, com a presença do "Meritíssimo Doutor Juiz de Direito da Câmara e cidadão Manoel José de Freitas Travassos Filho e o Doutor Promotor Público, o cidadão Antônio Alves Guimarães de Azambuja, jurado comigo escrivão interino de Júri” " ${ }^{16}$ O primeiro processo data de 1846 e refere-se ao assassinato do "cabra Thomaz" praticado pelo preto João, ambos escravos de Henrique Panitz, ocorrido em doze de junho. O réu foi imediatamente preso e aguardou o julgamento que ocorreu na "Sala da Casa das Sessões do Júri”, da Câmara Municipal de São Leopoldo, 
somente no dia dezessete de dezembro do mesmo ano. ${ }^{17} \mathrm{O}$ processo não foi apresentado ao Juiz de Direito na primeira sessão porque os jurados não compareceram em número correspondente ao de cidadãos qualificados, assim, o mesmo foi apresentado na segunda sessão e julgado na terceira.

Outra questão, que já mencionamos ao longo do texto, é o fato de que o Tribunal do Júri não possuía um prédio próprio. As sessões eram realizadas numa sala junto à Câmara Municipal de São Leopoldo. Como cabia aos municípios prover os prédios públicos, como Câmara Municipal, Cadeia, Delegacia de Polícia, geralmente as instalações eram precárias. O Presidente da Província, José Antônio Pimenta Bueno, na abertura da Assembleia Legislativa Provincial, em 1850, aponta que "[...] as municipalidades da província em geral não têm edifícios decentes para seus trabalhos, nem tampouco para as reuniões do Júri”. ${ }^{18}$ A falta de espaços adequados ou a mudança constante de local, como ocorreu em São Leopoldo, contribuíam para dificultar o andamento da Justiça. $\mathrm{O}$ julgamento dos processos judiciais preocupava, de forma constante, as autoridades, pois quanto mais demorado fosse o julgamento dos réus, mais tempo estes permaneciam nos "[...] maus edifícios, que servem de prisão" (BUENO, 1850, p. 39).

É possível perceber tanto nos relatórios do Presidente da Província quanto nos relatórios do Ministério da Justiça a preocupação das autoridades com o funcionamento dos órgãos responsáveis por manter a ordem e a tranquilidade na Província e no Império. Por exemplo, em 1847, José Antônio Pimenta Bueno informa que "[...] a situação moral do país, no tocante à administração da Justiça, não é satisfatória, e tanto mais sensível me é dizê-lo, quanto estou persuadido, que a falta de sua imparcial distribuição é um dos maiores flagelos da sociedade" (1847, p. 6). ${ }^{19}$ A justiça no Império e, em especial, o Tribunal do Júri, foi alvo de inúmeras críticas. Anualmente, mencionavam-se problemas, como a ineficiência, falta de profissionais e necessidade de melhorar a justiça no Brasil. Euzébio de Queiroz Coitinho Mattoso Câmara acreditava, em 1849, que o "[...] Júri é uma instituição, que garantindo a liberdade, ilustra o povo, e poderosamente concorre para enobrecer, e acreditar o poder judiciário [...] ", 
Atuação e funcionamento da Justiça no Brasil Imperial: o caso...

e a boa administração desta "[...] é sem dúvida [...] o maior beneficio e também a primeira necessidade das sociedades modernas" ${ }^{20}$

Com o regresso dos conservadores ao poder, o Tribunal do Júri teve sua estrutura modificada pela Reforma de 1841. Com a extinção do júri de acusação, "[...] o tribunal passou a ter somente uma parte de sua atribuição, determinando os fatos delituosos, além de ter perdido a função para julgar alguns tipos de crimes, que passaram à alçada das forças policiais” (BETZEL, 2006, p. 61). Mesmo que os Presidentes da Província reconhecessem a incipiente criminalidade na Província, observa-se que o Tribunal do Júri foi responsável pelo julgamento de crimes maiores, geralmente crimes violentos, como homicídios, ferimentos e ofensas físicas. Esses tipos de crimes prevaleciam nas estatísticas do Ministro da Justiça, do Presidente da Província do Rio Grande do Sul e também em São Leopoldo. Enquanto os crimes menores podiam ser resolvidos por um Juiz Municipal ou Delegado e Subdelegado de Polícia, os crimes graves eram remetidos ao Júri, conforme prescritos pelo código. Os acusados de crime levados ao Tribunal do Júri, frequentemente, recebiam a absolvição. Essa conduta foi alvo de inúmeras críticas, enquanto as autoridades questionavam o Júri por não cumprir seu papel, outras justificavam pela ineficiência a conduta do Juiz de Paz, responsável pela formação de culpa (BETZEL, 2006, p. 83). Thomas Flory também destaca a preocupação do governo central em relação à instituição do Tribunal do Júri, naquilo que tange aos longos julgamentos e às numerosas absolvições, mas principalmente pelo fato de ser uma força local, cuja decisão pela absolvição ou condenação dos réus cabia ao Conselho de Jurados. O número excessivo de absolvições decorria da intimidação dos jurados, ameaça às testemunhas, falta de segurança das cadeias e apadrinhamentos políticos (FLORY, 1986, p. 187).

Além do Juiz de Direito, Juiz Municipal e Promotor, que eram escolhidos pelo Imperador, compunham a sessão do Júri os jurados. Constatamos que nem sempre os cidadãos relacionados na lista de jurados compareciam às sessões. $\mathrm{O}$ processo que analisamos anteriormente demonstra que a sessão que julgaria o réu Carlos Trott foi adiada porque faltou o número legal de jurados, conforme prescrevia a lei. Provavelmente a distância entre os 
distritos e o Termo da vila de uma mesma comarca, motivo de doença pessoal ou familiar e recusa em assumir a função justificam o não comparecimento dos homens qualificados como jurados (MHVSL, documentos diversos, 1846-1871). A escassez de pessoas habilitadas para os cargos mais importantes da justiça, em algumas comarcas, era pauta constante nos relatórios provinciais. O Juiz de Direito, bacharel em Direito, que deveria presidir as sessões, muitas vezes, não estava no seu lugar, porque, frequentemente, poderia ser removido para outros lugares da Província do Rio Grande do Sul ou fora dela, devido à demora entre a nomeação e a posse na respectiva comarca, ou ainda devido às licenças concedidas pelas autoridades judiciárias, que poderiam durar meses. Sodré lembra que somente os juízes de direito, magistrados de primeira instância, recebiam ordenado. Contudo, o valor definido pela administração provincial não era sinônimo de fonte de renda e de permanência na função. ${ }^{21}$ "Em alguns casos, a falta de estímulo monetário era responsável por recusas, mas havia muitos outros motivos alegados pelos indicados" (SODRÉ, 2007, p. 7). Dessa forma, era comum encontrar nas comarcas da província pessoas que dividiam o tempo entre interesses públicos e privados. "Não raro também se observa a mesma pessoa ocupando diferentes cargos nas administrações e na política municipais, por exemplo, coletor de rendas, vereador, delegado, escrivão, entre outros" (SODRÉ, 2007, p. 7). No ano de 1855 , por exemplo,

[...] dos 8 juízes de direito, que há na província, apenas o da comarca do Rio Grande se acha atualmente em exercício, tendo-se o mês passado recolhido da corte onde fora tomar assento na câmara dos deputados. Todas as outras comarcas se acham acéfalas [...] e o cargo de chefe de polícia, por não ter voltado ainda o seu proprietário, e por não haver outro juiz de direito em exercício, quando tomei conta da administração da província, está sendo exercido presentemente pelo juiz municipal de um dos termos da comarca desta capital, o bacharel Francisco Coelho Borges, que tem desempenhado satisfatoriamente esse laborioso emprego (RELATÓRIO DO PRESIDENTE DA PROVÍNCIA, 1855, p. 8). 
Atuação e funcionamento da Justiça no Brasil Imperial: o caso...

Diante da situação descrita pelo Presidente da Província, verificamos, nos processos criminais e em outros documentos oficiais, suplentes ocupando espaços que deveriam ser presididos por bacharéis formados. Tais dificuldades contribuíram para tornar a administração da Justiça no Império mais frágil, visto que esses problemas não ocorriam unicamente na província sulina, mas permeavam o discurso imperial. "De tudo isto resulta a maior confusão e irregularidade na distribuição da Justiça, que está nas mãos de juízes iletrados, e sem as necessárias qualidades para tão importantes funções”. O Presidente da Província reitera ainda que “[...] apesar da ausência dos juízes de direito tem funcionado o Tribunal do Júri em quase todos os termos onde se devia reunir". ${ }^{22}$ Constatamos, de fato, que as sessões ocorriam todos os anos de seis em seis meses no Termo de São Leopoldo. Thomas Flory (1986, p. 187) afirma que "[...] as sessões não eram curtas, por lei duravam pelo menos duas semanas, e podiam estender-se até uma semana mais, dependendo do volume de trabalho". Os mapas de julgamentos proferidos pelo Júri, em anexo nos relatórios do Presidente de Província, e as Atas das Sessões do Júri indicam que no Termo de São Leopoldo as sessões ocorriam duas vezes por ano, e a duração de cada sessão podia variar de um até nove dias consecutivos ${ }^{23}$, pois tudo dependia do número de processos apresentados para julgamento. No ano de 1850, de 22 a trinta de janeiro, foram julgados sete processos. Dos nove réus, sete foram absolvidos, um condenado a prisão simples, um a açoites (escravo) e outro a pagar multa.

$\mathrm{Na}$ documentação pesquisada, encontramos recorrentemente ofícios de queixa contra pessoas que ocupavam, geralmente, mais de um cargo, falta de pessoas para ocupar cargos e ainda numerosos pedidos de dispensa. Em correspondência recebida no ano de 1859, o Presidente da Província informa ao Presidente da Câmara Municipal que foi "[...] declarado incompatível o exercício de ambos aqueles cargos [...]” de Juiz Municipal e de Órfãos e vereador em São Leopoldo. Estabelece como regra que, nesse caso, fosse chamado outro vereador para assumir a função. ${ }^{24}$ Andresa Silva da Costa (2004, p. 18) também constatou que havia a alternância na ocupação dos cargos administrativos e judiciais. "Delegados de polícia que aparecem em determinados processos como juízes municipais, em outros como 
advogados de uma das partes, ou como escrivão, ou, até mesmo, como integrante de júri popular”. Segundo a autora, essa alternância contribuiu para difundir a ideia de dinâmica na sociedade imperial e participação política dos imigrantes em São Leopoldo, visto que tanto os nacionais quanto os imigrantes disputaram espaços no poder político e jurídico. Mas essas disputas também “[...] podiam chegar a níveis de violência [...]”, como aconteceu, por exemplo, com o advogado Francisco Ferreira Bastos, assassinado em cinco de julho de 1867 (COSTA, 2004, p. 10-22). ${ }^{25}$

O Tribunal do Júri de São Leopoldo foi instalado no ano de 1846 e, apesar de alguns percalços, reuniu-se regularmente todos os anos, realizando duas sessões anualmente e obedecendo aos ritos processuais prescritos pela lei. $\mathrm{O}$ processo envolvendo o réu Carlos Trott e a vítima José Ness mostrou que em algumas ocasiões as sessões poderiam ser adiadas, devido à falta do número legal de jurados, contudo, na maioria das vezes, as sessões alcançavam o número de eleitores para realizar os julgamentos. Por fim, cabe salientar que os problemas relativos à falta de profissionais qualificados para ocupar os cargos mais importantes da administração da justiça, a ausência e multa aos jurados, as inúmeras absolvições dos réus pelos jurados não ocorreram exclusivamente no Júri de São Leopoldo, mas permearam a estrutura e a administração dos Tribunais no restante do país.

\section{“Tão escandalosamente absolvido pelo Júri”: atuação e sentenças}

No que tange à atuação do Tribunal do Júri no Termo de São Leopoldo, comprovou-se que, independentemente do tipo de delito e posição social do(s) réu(s) ou da(s) vítima(s), o número de absolvições foi superior ao de condenações. Dos 157 réus contabilizados, 116 foram absolvidos pelos jurados, ou seja, quase 74\% da nossa amostragem, e somente 11,5\% dos réus sofreram algum tipo de condenação (dezoito pessoas foram condenadas), visto que o tipo de crime que prevaleceu em São Leopoldo foi o crime 
contra a pessoa (homicídio, tentativa de homicídio, agressão física e ferimentos, ofensas verbais e outros). Assim, no Termo de São Leopoldo, como no restante da Província e do Império, o Júri promoveu frequente absolvição dos réus. As recorrentes estatísticas de absolvições enviadas pelas comarcas ao Presidente da Província devem ter contribuído para o mesmo informar que,

[...] apesar da qualidade dos juízes a que as substituições sucessivas levam, são tantos os meios de inutilizar os efeitos de qualquer sentença boa ou má, que não é impossível alcançar-se que enfim as decisões possam ser justas, mas nos casos de justiça criminal melhor dizer que a palavra Justiça - é vazia de sentido". ${ }^{26}$

Tabela 2 - Sentença proferida aos réus (1846-1871)

\begin{tabular}{c|c|c}
\hline Sentença proferida pelo Júri & Incidência da sentença & Porcentagem \\
\hline Absolvição & 116 & $73,9 \%$ \\
\hline Condenação & 18 & $11,5 \%$ \\
\hline Despronúncia & 17 & $10,8 \%$ \\
\hline Morte & 1 & $0,6 \%$ \\
\hline Ausência & 5 & $3,2 \%$ \\
\hline Total & $\mathbf{1 5 7}$ & $\mathbf{1 0 0 \%}$ \\
\hline
\end{tabular}

Fonte: Elaborado pela autora com base em: APERS, processos criminais, 1846-1871.

A partir dos dados compilados na tabela dois, comprova-se que o Júri do Termo de São Leopoldo também absolvia mais que condenava. Além de ser uma realidade em muitas comarcas do Império, tal postura poderia estar associada, por um lado, ao fato de que esses indivíduos se conheciam, frequentavam os mesmos espaços de lazer e sociabilidade e possuíam negócios em comum (trabalho, parcerias, dívidas). Se compararmos o perfil dos réus e dos jurados, podemos observar que eles ocupavam profissões ligadas 
à agricultura, a profissões artesanais e manuais, logo, a maioria residia na área rural, ou seja, nos distritos da Vila e Cidade de São Leopoldo. Por outro lado, o número de absolvições poderia refletir a legitimidade por parte dos jurados, naquilo que tange à postura e conduta dos réus diante de situações conflituosas do dia a dia. Dessa maneira, as relações existentes entre o acusado, a vítima e os jurados poderiam interferir na atribuição da pena, cuja decisão jurídica era proferida pelo Juiz de Direito em exercício.

Aqui não incluímos os processos que não foram julgados pelo Júri, isto é, aqueles que chegaram às mãos de Juízes Municipais, Delegados de Polícia e Subdelegados de Polícia. Vale lembrar que os crimes menores como vadiagem, embriaguez ou ofensas verbais, ocorridos quase diariamente, eram incumbência da polícia sentenciar, enquanto para os crimes maiores (crimes de sangue) recorria-se a processos formais julgados pelo Tribunal do Júri. A partir das sessões realizadas anualmente, determinava-se uma sentença ao réu. Quase 74\% das sentenças proferidas pelo Tribunal do Júri decidiram pela absolvição dos réus. Entre os dezoito casos de condenação, observamos que os réus foram condenados a prisão e multas correspondentes ao tempo de reclusão, galés perpétuas e açoites (escravos). A tabela a seguir apresenta as condenações imputadas aos dezoito réus dos processos julgados pelo Júri do Termo de São Leopoldo. 
Atuação e funcionamento da Justiça no Brasil Imperial: o caso...

Tabela 3 - Condenações impostas pelo Júri (1846-1871)

\begin{tabular}{c|c|c}
\hline Tipo de condenação & Incidência no termo & Porcentagem \\
\hline Prisão de 1 a 12 meses & 2 & $11,1 \%$ \\
\hline Prisão de 1 a 5 anos & 5 & $27,8 \%$ \\
\hline Prisão de 5 a 10 anos & 4 & $22,2 \%$ \\
\hline Prisão acima de 10 anos & - & - \\
\hline Açoites & 3 & $16,7 \%$ \\
\hline Condenado à morte & - & - \\
\hline Condenado a galés perpétuas & 4 & $22,2 \%$ \\
\hline Total & $\mathbf{1 8}$ & $\mathbf{1 0 0 \%}$ \\
\hline
\end{tabular}

Fonte: Elaborado pela autora com base em: APERS, processos criminais, 1846-1871.

Acerca dos dezoito réus condenados pelo Tribunal do Júri, é interessante destacar que a cor ou a condição social parece não ter sido o indicativo que favoreceu a condenação dos réus. Dos nove processos encontrados cujos réus eram escravos, cinco deles receberam a condenação mínima ou média, como açoites e alguns anos de prisão. Quanto aos réus condenados a galés perpétuas, cabe destacar que os mesmos foram condenados a cumprir alguns meses ou anos, sendo um destes de origem alemã. Constatamos que a maioria dos réus condenados não eram escravos, mas sim pessoas de origem luso-brasileira (oito réus), apesar de a maioria dos réus nos processos levados ao Júri serem alemães e seus descendentes.

Ao longo do século XIX, o Tribunal do Júri foi alvo de duras críticas. Mencionamos anteriormente que o Tribunal do Júri e, em especial, o conselho de jurados, foi visto pelas autoridades como uma instituição que promovia a impunidade, a ineficiência e a falta de garantia na aplicação da justiça, sendo os jurados os principais responsáveis. Tanto nos relatórios do Ministro da Justiça quanto dos Presidentes da Província, perdurou a ideia de que o Júri "[...] atrapalhava e inutilizava os esforços da Polícia em tentar corrigir os crimes" (BETZEL, 2006, p. 89). Ivan Vellasco (2004, p. 144), acerca desse assunto, destaca que, na Comarca do Rio das Mortes, 
em Minas Gerais, “[...] as coisas não iam tão mal [...]” quanto apontavam os críticos à instituição do Júri. Para ele, tais queixas assumiram "ares de uma campanha pelo seu [sistema de jurados] progressivo esvaziamento". As opiniões sobre o sistema de jurados eram variadas entre os contemporâneos.

Para tentar traçar um perfil dos cidadãos qualificados como "Juízes de Fato", recorremos aos livros intitulados Sorteio de Jurados, localizados no Memorial do Judiciário para o período de 1846 a $1871 .{ }^{27}$ A primeira informação a que tivemos acesso foi o número de cidadãos qualificados para cada ano. Além da lista geral, anotava-se no mesmo livro a relação dos jurados sorteados para cada sessão, bem como a relação dos jurados suplentes, somente a partir de 1850 . Como o Tribunal do Júri de São Leopoldo realizava duas sessões por ano, logo, realizavam-se dois sorteios: 48 cidadãos para compor a primeira sessão e 48 para a segunda. $\mathrm{O}$ gráfico a seguir traz um levantamento quantitativo do número de cidadãos qualificados e relacionados na lista geral.

\section{Gráfico 1 - Número de cidadãos qualificados por ano}

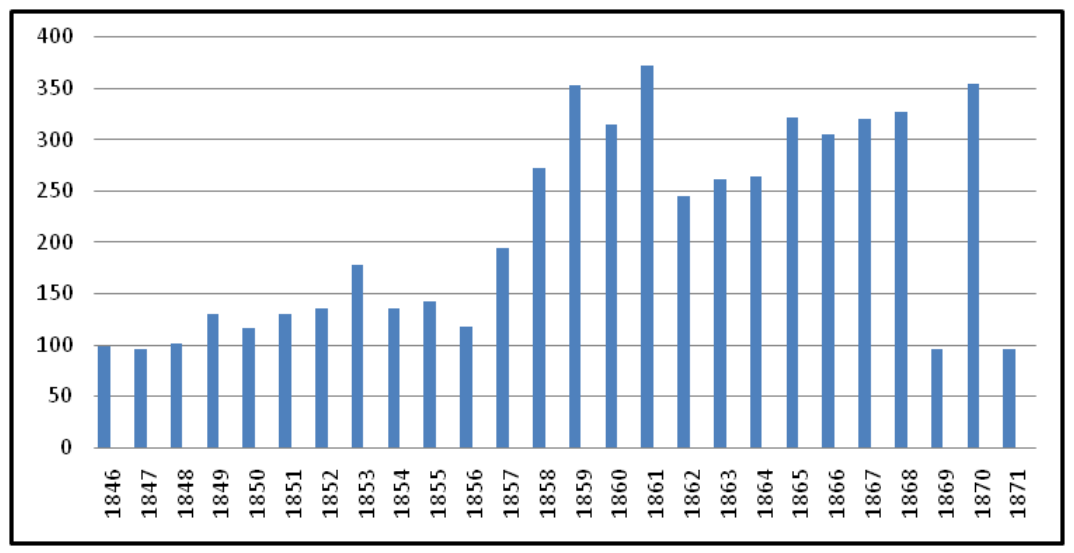

Fonte: Elaborado pela autora com base em: Memorial do Judiciário. Sorteio de Jurados, número 414, maço 24, estante 77, 1846 a 1862; Memorial do Judiciário. Sorteio de Jurados, número 420, maço 24, estante 77, 1862 a 1871. 
Atuação e funcionamento da Justiça no Brasil Imperial: o caso...

Para os anos 1847, 1869 e 1871 não encontramos a lista geral com a relação das pessoas qualificadas. $\mathrm{O}$ método utilizado nesses casos foi contabilizar 96 jurados para cada ano, ou seja, 48 pessoas qualificadas por sessão, partindo do pressuposto de que foram realizadas duas por ano. Ao observar o gráfico um, podemos perceber que, nos primeiros anos da amostra, de 1846 a 1856, o número de cidadãos que atendiam às exigências previstas pelo Código Criminal era mais modesto, enquanto do ano de 1857 em diante houve um aumento, mas o número variava de um ano para o outro. No ano de 1861, temos o maior número de cidadãos inclusos na lista geral: foram 373 jurados.

Os dados apresentados nos levaram a duas hipóteses: uma de que nos primeiros anos a vila ainda sentia as sequelas da Revolução Farroupilha e necessitava reorganizar-se administrativamente. Quando restabeleceu-se a tranquilidade na vila, conforme afirma Jean Roche (1969, p. 17), São Leopoldo voltou a prosperar. Fatores como posição estratégica, elevação da Capela Curada à condição de Vila, desenvolvimento econômico, nova condição política, além da retomada da colonização e a Lei de Naturalização ${ }^{28}$, sob número 397, de três de setembro, contribuíram, por um lado, para acirrar os ânimos e, por outro, para o desenvolvimento da Colônia. Assim, com o rápido crescimento da população e o desenvolvimento econômico, gradativamente mais pessoas atendiam aos requisitos para ocupar a função de jurado.

Não sabemos se existia uma lista padrão a ser seguida pelo Júri quanto às informações acerca de cada jurado qualificado, contudo, identificamos que o Tribunal do Júri de São Leopoldo não seguia um padrão, pois, para alguns anos, o escrivão registrou somente o nome dos cidadãos, e em outras listas encontramos o nome e local de residência do jurado. Encontramos, dessa forma, apenas cinco listas onde o escrivão registrou o nome, a profissão exercida, a renda anual de cada jurado e o local de moradia. Mesmo não contando com as informações de todo o período em estudo, a quantificação dos dados encontrados nas listas de 1855 a 1859 nos permitirá ter uma ideia do perfil social de quem era escolhido para ser jurado.

A partir de 1846, sujeitos como Humberto de Schlabrendorff, Júlio Henrique Knorr, Pedro Francisco Afonso Mabilde, Cristiano 
Fischer, André Herzog, João Pedro Schmidt, João Daniel Hillebrand e Pedro Hass solicitaram as suas naturalizações, pois a partir da Lei n. 397 passavam a ser reconhecidos como cidadãos e, assim, poderiam ocupar cargos da municipalidade como ser jurado. Esses nomes apareceram com frequência nas listas gerais, todavia, no ano de 1855, o número de alemães e descendentes qualificados correspondia a $18 \%$ da amostragem total, isto é, apenas 22 dos 143 cidadãos. No ano seguinte, o número de jurados de origem teuta diminuiu para apenas nove indivíduos.

Quanto às profissões, em São Leopoldo, a maioria dos cidadãos qualificados como jurado ocupava-se de profissões rurais: lavrador e fazendeiro era a ocupação exercida pela maioria dos cidadãos, tanto de origem teuta quanto pelos nacionais. Desse modo, prevaleceu em São Leopoldo a qualificação de jurados que se ocupavam de profissões ligadas à agricultura. Em relação aos cidadãos de origem luso-brasileira, além de lavradores, também encontramos jurados que ocupavam a função de empregado público, alguns negociantes e professores. Já em relação aos alemães e descendentes, a segunda ocupação profissional que prevaleceu foram as atividades manuais e artesanais, além de alguns negociantes. Esses dados refletem as características de São Leopoldo. Nessa época, a Vila de São Leopoldo dividia-se administrativamente em cinco freguesias: São Leopoldo, Santa Cristina do Pinhal, Santa Anna do Rio dos Sinos, São Miguel e São José do Hortêncio. Com uma população de 18.690 indivíduos, em 1858, a Vila de São Leopoldo sentia os reflexos do crescimento populacional, e tornava-se um importante polo exportador do excedente (produzido nas lavouras da zona rural tanto por teutos quanto por luso-brasileiros) para Porto Alegre. Quanto à qualificação de jurados, cabe ressaltar que, da população total, somente 272 cidadãos enquadraram-se nos requisitos exigidos pela lei, isto é, apenas $1.4 \%$ da população total de 1858 .

De acordo com os dados compilados do livro Sorteio dos Jurados, de 1846 a 1871, constatamos que os luso-brasileiros foram chamados com mais frequência para compor o conselho de jurados. No ano de 1859, a participação de teuto-brasileiros chegou a 38\% do total de 354 jurados qualificados, ou seja, um índice bem superior se comparado com o ano de 1856, quando apenas pouco menos de 
Atuação e funcionamento da Justiça no Brasil Imperial: o caso...

$8 \%$ dos jurados eram de origem teuta. Com o passar dos anos e em decorrência do desenvolvimento econômico da Vila e Cidade de São Leopoldo, o número de jurados qualificados por ano aumentou, e, possivelmente, o número de cidadãos de origem teuto-brasileira também subiu, fato que permite observar que um maior número de indivíduos descendentes de alemães atingiu os requisitos exigidos para ser eleitor e, posteriormente, jurado. Constatou-se também não terem prevalecido no Termo de São Leopoldo homens ignorantes ou analfabetos. Ao contrário, as pessoas que compunham o conselho de jurados pelo menos sabiam ler e escrever, visto que todos sabiam assinar seu nome. Embora a lei exigisse que o jurado fosse alfabetizado para ocupar o cargo de jurado, para Thomas Flory (1986), na prática, isso não aconteceu em muitos termos.

É interessante destacar que, entre os descendentes de alemães, com frequência, os jurados assinavam o seu nome em alemão gótico, outros, por sua vez, já sabiam escrever em letra rotunda. A participação crescente de teuto-brasileiros como jurados, especialmente em 1859, demonstra a inserção social de uma parcela dos imigrantes na economia (os eleitores e jurados precisavam comprovar seus rendimentos), nas instâncias política, administrativa e judicial do Termo, pois exercer a função de jurado poderia ser uma excelente oportunidade para o cidadão brasileiro participar das atividades do Estado. José Murilo de Carvalho (1996, p. 345-388), baseado na opinião de Pimenta Bueno, lembra que "[...] o júri era o baluarte da liberdade política contra os abusos do poder, uma garantia da independência judiciária, um tesouro que era preciso preservar e aperfeiçoar [...]”, pois ser jurado no Brasil Imperial não significava unicamente votar, mas também a oportunidade de participar do poder judicial.

Enquanto alguns jurados não compareciam às sessões, devido a alguma questão de saúde, distância da sede da Vila e Cidade ou sem justificativa, outros, no entanto, percorriam longas distâncias para exercer sua função. Assim, identificamos, nas cinco listas (1855 a 1859), que indivíduos percorriam de uma até nove léguas para se apresentar às sessões e cumprir com a sua função de absolver ou condenar os réus. Apesar das críticas, para José Murilo de Carvalho (2013, p. 37), “[...] quem participava do Júri sem dúvida 
se aproximava do exercício do poder e adquiria alguma noção do papel da lei”. Segundo o mesmo autor, "[...] em torno de $80 \mathrm{mil}$ pessoas exerciam a função de jurado em 1870”.

\section{Considerações finais}

A inserção de um sistema de jurados no cenário judicial significou um aumento no número de cidadãos envolvidos com a rotina dos tribunais e uma aproximação da população local no século XIX. Todavia, esse sistema foi alvo de inúmeras críticas, expressas nos relatórios ministeriais, relatórios dos presidentes da província, bem como na historiografia. Para o Ministro da Justiça João Lins Vieira Cansansão de Sinimbú, por exemplo,

[...] os cidadãos ainda não se compenetraram da importância do julgamento pelos pares, garantia que este Tribunal oferece à sociedade e aos indivíduos. Muitas decisões evidentemente injustas e absurdas são sem dúvida a causa dessa falta de fé na instituição do Júri. [...] o maior defeito que noto no Tribunal, como o temos constituído, é a demora do julgamento. $\mathrm{Na}$ máxima parte das localidades as reuniões fazem-se de seis em seis meses; em muito poucas os jurados são convocados de dois em dois meses. Uma prisão sem julgamento por seis meses é um vexame que não tem justificação possível, é um gravíssimo mal na administração da Justiça Criminal. ${ }^{29}$

De fato, a descrição do Ministro da Justiça era uma realidade em muitas comarcas do Império. Mesmo diante de inúmeras queixas acerca do funcionamento da instituição jurídica, e, principalmente, na dificuldade de qualificar o número de jurados para compor as sessões, podemos afirmar que no Termo de São Leopoldo as sessões do Tribunal do Júri ocorriam todos os anos, conforme previa a legislação imperial, isto é, de seis em seis meses, e geralmente com o número de jurados determinado pela lei.

O levantamento dos dados apresentados acerca do Conselho de Jurados do Termo de São Leopoldo demonstra que indivíduos 
de cor branca, chefes de família, com posição econômica e renda variada prevaleceram nessa função. Parece não terem prevalecido nesse Termo jurados ignorantes ou analfabetos, mas, ao contrário, pessoas de destaque na sociedade local, que ao mesmo tempo participavam do Conselho de Jurados e ocupavam cargos públicos e outros ofícios, como Delegado de Polícia, Subdelegado de Polícia, Juiz de Paz, Inspetor de Quarteirão, Tabelião, Policial, professor, advogado, negociante, lavrador e outros. As informações coletadas da Lista Geral permitiram mostrar que o Conselho de Jurados era composto por cidadãos com formação socioeconômica heterogênea. Forros, mulheres, pobres livres e escravos, por sua vez, eram excluídos do Conselho de Jurados, e essa exclusão contribuiu para formar um grupo restrito, composto por nacionais, alemães e teuto-brasileiros.

Além do número expressivo de absolvições ( $74 \%$ dos réus processados serem absolvidos pelo Tribunal do Júri), outros fatores, como a ausência constante de autoridades policiais e judiciais no termo e nos distritos de São Leopoldo, o controle e a vigilância desigual na parte rural e urbana, as péssimas condições da maioria das estradas que ligavam a sede e os distritos contribuíram para que muitos casos fossem resolvidos por conta própria ou através do uso da violência física. Contudo, essa postura demonstra que a violência praticada em São Leopoldo, entre 1846 e 1871, foi considerada legítima e necessária pelos jurados, em alguns casos, visto que julgaram correta a atitude e aceitaram os argumentos apontados pela maioria dos réus. Mesmo quando o desentendimento resultasse em morte, os testemunhos poderiam inocentar o acusado por acreditarem que a conduta havia sido legítima. Por fim, cabe destacar que a violência empregada como prática de justiça local não foi somente legítima para a comunidade que deveria conviver com os transgressores, mas também para a Justiça institucional que decidiu pela absolvição dos réus. 


\section{PERFORMANCE AND FUNCTIONING OF JUSTICE IN BRAZIL IMPERIAL: THE CASE OF THE COURT OF THE JURY OF SÃO LEOPOLDO / RS}

Abstract: The purpose of this article is to analyze how institutional justice was applied in the interior of the Province of Rio Grande do Sul, with a view to the installation and operation of the São Leopoldo Jury Court. Although there has been an increasing number of work in recent years on the study of official justice and its agents on the national and regional scene, there is still a lack of studies on local official justice, and especially comparative analyzes that consider non-official justice practices existing in the colonies. From diverse sources, found in the Judicial Memorial, in the Historical Archive of Rio Grande do Sul, in the Public Archive of Rio Grande do Sul and in other archives, we seek to promote a reflection on Justice in São Leopoldo in the second half of the 19th century. To achieve this objective, methodologically, we will analyze the sources in a quantitative and qualitative way, as well as promote their cross-referencing, in order to find evidence about the Jury Court, jurors, defendants and victims. Keywords: Jury court. São Leopoldo. $19^{\text {th }}$ century.

\section{Notas}

${ }^{1}$ Disponível em: http://www.planalto.gov.br/ccivil_03/decreto/Historicos/DIM/ DIM-18-7-1822.htm. Acesso em: 03 dez. 2014.

${ }^{2}$ APERS, Processo criminal, $\mathrm{n}^{-\mathrm{a}}$ 73, maço 3, estante 77, 1866.

${ }^{3}$ Os processos criminais ex officio iniciavam por intermédio de um oficial da Justiça, ou seja, podiam ser instaurados pelo Delegado de Polícia, a partir da vigência da Lei 262, de 1841, que criou os cargos de Chefe de Polícia, Delegado e Subdelegado de Polícia (CAMPOS; BETZEL, 2006, p. 77).

${ }^{4}$ De acordo com Marcos Bretas (1991, p. 50), os discursos dos réus, das vítimas e testemunhas são construídos especialmente "[...] para responder às expectativas de um outro grupo, os funcionários da justiça”, pois é através da ação do escrivão que as falas se transformam em depoimentos nos processos.

${ }^{5}$ MHVSL, Câmara Municipal de São Leopoldo, 1847-1889, Função Judiciária, caixa 1, Doc. 18, 15/06/1854.

${ }^{6}$ APERS, Processo criminal, $\mathrm{n}^{\mathrm{a}}$ 73, maço 3, estante 77, 1866: fl. 41.

${ }^{7}$ APERS, Processo criminal, $\mathrm{n}^{\mathrm{a}}$ 73, maço 3, estante 77, 1866: fl. 42.

${ }^{8}$ APERS, Processo criminal, n⿳a 73, maço 3, estante 77, 1866: fl. 47.

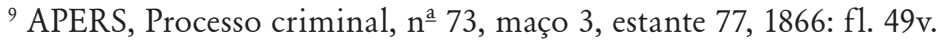

${ }^{10}$ MHVSL, Câmara Municipal de São Leopoldo, 1847-1889, Função Judiciária, caixa 1 , Doc. $4,10 / 10 / 1858$. 
Atuação e funcionamento da Justiça no Brasil Imperial: o caso...

${ }^{11}$ MHVSL, Câmara Municipal de São Leopoldo, 1847-1889, Função Judiciária, caixa 1, Doc. 27, 23/08/1858.

12 MEMORIAL DO JUDICIÁRIO, Livro de Multas, número 413, maço 24, estante 77, 14/12/1846 a 28/06/1896.

${ }^{13}$ APERS, Processo criminal, $\mathrm{n}^{\mathrm{a}}$ 73, maço 3, estante 77, 1866: fl. 71v.

${ }^{14}$ APERS, Processo criminal, $\mathrm{n}^{\mathrm{a}}$ 73, maço 3, estante 77, 1866: fl. 72.

${ }^{15}$ APERS, Processo criminal, $\mathrm{n}^{\mathrm{a}}$ 73, maço 3, estante 77, 1866: fl. 72v.

${ }^{16}$ MEMORIAL DO JUDICIÁRIO. Atas da sessão do Júri, número 16, maço 24, estante 77, 1846-1860, fl. 1.

${ }^{17}$ APERS, Processo crime, Tribunal do Júri, número 02, maço 01, estante 77, 1846.

${ }^{18}$ BUENO, José Antônio Pimenta. Relatório do presidente da Província de São Pedro do Rio Grande do Sul, na abertura da Assembleia Legislativa Provincial em primeiro de outubro de 1850; acompanhado do orçamento da receita e despesas para o ano de 1851. Porto Alegre, Typ. de F. Pomatelli, 1850, p. 37.

${ }^{19}$ BUENO, José Antônio Pimenta. Relatório da Repartição dos Negócios da Justiça apresentado à Assembleia Geral Legislativa na primeira Sessão da 7은 Legislatura. Rio de Janeiro: Typ. do Diário, de N. L. Vianna, 1847, p. 6.

${ }^{20}$ CÂMARA, Euzébio de Queiroz Coitinho Mattoso. Relatório da Repartição dos Negócios da Justiça apresentado à Assembleia Geral Legislativa na primeira Sessão da $8^{\circ}$ Legislatura em 1850. Rio de Janeiro: Typ. do Diário, de N. L. Vianna, 1849 (1ํ), p. 22, p. 25.

${ }^{21}$ O Presidente da Província, Euzébio de Queiroz Coitinho Mattoso Câmara, no relatório de 1849 (p. 29), informa que "[...] os nossos juízes de direito na maior parte das províncias recebem apenas 1:200\$000, 1:400\$000, e 1:600\$000 de ordenados a percorrer várias vezes no ano longas distâncias para presidir às sessões do Júri. Por isso, dois quintos dos juízes de direito se conservam na época anteriormente referida fora de seus lugares, e é forçoso acrescentar que os outros, geralmente falando, não perdem ocasião de fugir à onerosa, mas importante contribuição de presidir às sessões do Júri”.

${ }^{22}$ COELHO, Jerônimo Francisco. Relatório do presidente da Província de São Pedro do Rio Grande do Sul, na abertura da Assembleia Legislativa Provincial em quinze de dezembro de 1856. Porto Alegre: Typ. do Mercantil, 1856, p. 31. ${ }^{23}$ No ano de 1846, ocorreu uma sessão na qual foram julgados dois processos, entre quinze e dezoito de dezembro. Em 1848, foram três processos julgados, entre doze e quatorze de setembro. Um processo foi julgado em doze de fevereiro de 1849. Em 1850, ocorreram duas sessões, uma entre 22 e trinta de janeiro e outra entre oito e nove de outubro, julgando-se dez processos. Duas sessões ocorreram em 1851, e foram julgados três processos em 22 de fevereiro e 22 e 25 de outubro. Também foram julgados três processos em 1852, sendo que a primeira sessão ocorreu em 28 de fevereiro e a segunda entre vinte e 21 de setembro. No 
ano de 1853, encontramos o registro de apenas uma sessão ocorrida entre 21 e 22 de fevereiro, para julgar apenas um processo. Pulando o ano de 1854, foram realizadas duas sessões, no ano de 1855 . Em 1856, uma sessão ocorreu entre onze e treze de outubro. Sem informações para o ano de 1857, duas sessões ocorreram no ano seguinte. Entre 31 de maio e dois de junho e 24 de agosto, foram julgados três processos. As sessões do ano de 1859 foram realizadas nas mesmas datas do ano anterior, porém foram julgados dois processos. E, por fim, em 1861, realizaram-se duas sessões, julgando seis processos, entre quatro de março e 23 a 28 de abril. Para os demais anos, até 1871, não encontramos os mapas de julgamento em anexo nos relatórios. Porém, cabe destacar que algumas informações acerca dos julgamentos na Província do Rio Grande do Sul podem ser encontradas dispersas nos relatórios do Presidente da Província. Relatório do Presidente da Província, 1846-1871. Disponível em http://www-apps.crl.edu/ brazil/provincial/rio_grande_do_sul. Acesso em: 4 maio 2015.

${ }^{24}$ MHVSL, Câmara Municipal de São Leopoldo. Fundo Correspondência recebida, função executiva, caixa 1, Doc. 373, 21 de março de 1859.

${ }^{25}$ No ano de 1867, a viúva Maria Engracia de Jesus encaminha uma queixa contra os supostos mandantes Vicente Batista Orsi, João Lourenço Torres e Antônio Ferreira Tavares Leiria e os supostos executores Catharina Bach e Gabriel Carlson. De acordo com a viúva, "[...] o marido estava na sala da casa tratando de negócios com outros dois homens [...]”, quando, “[...] pela janela, veio um tiro partindo a vidraça que atingiu no peito seu marido". O crime, que ocorreu no dia cinco de julho, resultou na morte do advogado Francisco Ferreira Bastos. Segundo a autora, a vítima teria escrito uma carta, em que listava e denunciava inúmeras acusações contra os seus inimigos, que, por sua vez, eram personalidades de prestígio na Vila de São Leopoldo. "O Capitão da Guarda Nacional, Orsi, quando escrivão da Capela de Piedade (Novo Hamburgo), de combinação com o então subdelegado João Lorenço Torres, subtraiu um auto de corpo de delito por ocasião de um assassinato de um pardo cometido pelos irmãos Kruppet, sendo abafado o respectivo caso”. Antes de ser assassinado, Bastos foi ameaçado pelos réus, por ter recuperado o corpo de delito e por outras desavenças políticas e territoriais. Em setembro de 1867, apesar das provas, o Júri decidiu pela absolvição dos réus. A família recorreu da decisão, apelando ao Presidente da Relação, o desembargador Antônio da Costa Pinto, "[...] que manda que se marque novo Júri e novamente são absolvidos os réus, isso em maio de 1868". COSTA, Andresa Silva da. Um crime anunciado: o assassinato de Francisco Ferreira Bastos - contribuições para a História das Relações de Poder no Rio Grande do Sul do Século XIX. São Leopoldo: UNISINOS. Monografia (Licenciatura em História) - Universidade do Vale do Rio dos Sinos, 2004.

${ }^{26}$ ANDREA, Francisco José de Souza Soares. Relatório do presidente da província de São Pedro do Rio Grande do Sul, na abertura da Assembleia Legislativa 
Atuação e funcionamento da Justiça no Brasil Imperial: o caso...

Provincial em primeiro de junho de 1849, acompanhado do orçamento da receita e despesas para o ano de 1849-1850. Porto Alegre, Typog. do Porto-Alegrense, 1849, p. 1.

${ }^{27}$ Para o período em análise, encontramos dois livros intitulados Sorteio de Jurados, no Memorial do Judiciário. Um deles compreende o período de 1846 a 1862 (número 414, maço 24, estante 77); o outro de 1862 a 1871 (número 420, maço 24, estante 77). A partir dos nomes listados nos livros, foi possível criar o gráfico a seguir.

${ }^{28}$ Em três de setembro de 1846, sob número 397, foi decretada a Lei de Naturalização. Essa lei determinava que os estrangeiros estabelecidos em São Leopoldo e São Pedro de Alcântara das Torres fossem reconhecidos como cidadãos brasileiros, mediante assinatura de um termo junto à Câmara Municipal. A lei de naturalização deveria ser traduzida para o alemão e afixada em locais distintos da Vila de São Leopoldo. Tramontini lembra que, apesar da Câmara Municipal cobrar pelos certificados que deveriam ser fornecidos gratuitamente, vários alemães apresentaram-se requerendo naturalização. Entretanto, "[...] quando o alemão Henrique Bier declarou o desejo de naturalizar-se brasileiro, tanto a Câmara como a Presidência da Província começaram a ser mais rigorosos na aceitação dos pedidos, exigindo, neste caso, uma declaração sobre sua condição de colono, a data de sua vinda para o Brasil, qual colônia recebeu e se a cultivou. E em ofício da presidência à Câmara ordenava-se 'que não se deve passar mais declarações a indivíduo algum para requerer carta de naturalização, sem que seja colono', o que não correspondia às disposições da Lei de Naturalização, que fala claramente em 'estrangeiros atualmente estabelecidos nas colônias', o que não quer dizer exclusivamente 'colonos"' (TRAMONTINI, 2000, p. 6-7). ${ }^{29}$ SINIMBÚ, João Lins Vieira Cansansão de. Relatório do Ministério da Justiça que se devia apresentar à Assembleia Geral Legislativa na Terceira sessão da Décima Primeira Legislatura. Rio de Janeiro: Typ. Nacional, 1862, p. 13.

\section{Referências}

ARQUIVO HISTÓRICO DO RIO GRANDE DO SUL. Fundo Requerimentos, maço 104, 1863.

ARQUIVO PÚBLICO DO ESTADO DO RIO GRANDE DO SUL. Processos criminais, Tribunal do Júri, 1846-1889.

BETZEL, Viviani Dal Piero. O tribunal do júri: papel, ação e composição. Vitória/ES, 1850-1870. Espírito Santo, 2006. Dissertação (Mestrado em História) - Programa de Pós-Graduação em História, Universidade Federal do Espírito Santo - UFES, Espírito Santo, 2006.

Anos 90, Porto Alegre, v. 25, n. 47, p. 305-338, jul. 2018 
BISINOTTO, Edneia Freitas Gomes. Origem, história, principiologia e competência do tribunal do júri. Disponível em: http://www.ambitojuridico.com.br/ site/index.php?n_link=revista_artigos_leitura\&artigo_id=9185. Acesso em: 12 mar. 2016.

BOURDIEU, Pierre. A Dominação masculina. 2. ed. Rio de Janeiro: Bertrand Brasil, 2002.

BRETAS, Marcos Luiz. O crime na historiografia brasileira: uma revisão na pesquisa recente. In: Boletim Informativo e Bibliográfico de Ciências Sociais. Rio de Janeiro, n. 32, 1991.

CAMPOS, Adriana Pereira; BETZEL, Viviani Dal Piero. A Justiça e o júri oitocentista no Brasil. In: Revista Justiça \& História. v. 6, n. 12, 2006.

CARVALHO, Claudia Fernanda Souza de. Evolução histórica do Tribunal do Júri. Revista Jurídica - CCJ/FURB. v. 13, n. 26, jul./dez., 2009.

CARVALHO, José Murilo de. Cidadania no Brasil: o longo caminho. Rio de Janeiro: Civilização Brasileira, 2013.

COLEÇÃO DAS LEIS DO BRASIL (1808-1871). Disponível em: http://www4. planalto.gov.br/legislacao. Acesso em: 12 mar. 2017.

COLEÇÃO DAS LEIS DO IMPÉRIO DO BRASIL (1808-1871). Disponível em: http://www2.camara.leg.br/atividade-legislativa/legislacao/publicacoes/ doimperio. Acesso em: 12 mar. 2017.

COSTA, Andresa Silva da. Um crime anunciado: o assassinato de Francisco Ferreira Bastos - contribuições para a História das Relações de Poder no Rio Grande do Sul do Século XIX. São Leopoldo: UNISINOS. Monografia (Licenciatura em História) - Universidade do Vale do Rio dos Sinos, 2004.

FERREIRA, Augusto César Feitosa Pinto. Reformas judiciais e atuação da justiça criminal no Brasil Imperial: uma discussão historiográfica. Revista: Justiça \& História, Porto Alegre, v. 7, n. 14, 2007, p. 1-27.

FIGUEIRA, Luiz Eduardo. A organização do Tribunal do Júri e a questão da incomunicabilidade dos jurados no Brasil Imperial. In: CONPEDI/UFSC. (Org.). História do Direito. Florianópolis: CONPEDI, 2014, v. 1, p. 90-107. Disponível em: http://www.publicadireito.com.br/artigos/?cod=030869ecc70e9978. Acesso em: 23 ago. 2014.

FLORY, Thomas. El Juez de Paz y el jurado en el Brasil Imperial, 1808-1871: control social y estabilidad política el nuevo Estado. México: Fondo de Cultura Económica, 1986. 
Atuação e funcionamento da Justiça no Brasil Imperial: o caso...

MEMORIAL DO JUDICIÁRIO. Livro de Atas de sessão do Júri de 1846-1870, n. 415 e 418, maço 24, estante 77.

. Livro de Multas de jurados de 1846-1896, n. 413, maço 24, estante 77. . Livro de fianças, n. 423, maço 25, estante 77. . Livro de Sorteio de jurados de 1846-1871, n. 414 e 420, maço 24, estante 77. . Livro Rol de culpados de 1846-1873, n. 416, maço 24, estante 77.

MOEHLECKE, Germano Oscar. São Leopoldo: contribuição à história da vida política e administrativa (1824-2010). São Leopoldo: Oikos, 2011.

MUSEU HISTÓRICO VISCONDE DE SÃO LEOPOLDO, Câmara Municipal de São Leopoldo, Documentos diversos, 1846-1871.

NEQUETE, Lenine. O poder judiciário no Brasil a partir da Independência: I. Império. Brasília: Supremo Tribunal Federal, 2000.

RELATÓRIOS DO MINISTRO DA JUSTIÇA (1846-1871). Disponível em: http://www-apps.crl.edu/brazil/ministerial/justica. Acesso em: 12 mar. 2017.

RELATÓRIOS DO PRESIDENTE DA PROVÍNCIA (1846-1871). Disponível em: http://www-apps.crl.edu/brazil/provincial/rio_grande_do_sul. Acesso em: 12 mar. 2017.

SODRÉ, Elaine Leonara de Vargas. Do Código de Processo a Reforma de 1841: entre acertos e erros a organização judiciária na Província de São Pedro. In: SIMPÓSIO NACIONAL DE HISTÓRIA, 24, 2007, São Leopoldo, RS. XXIV Simpósio Nacional de História. Anais História e multidisciplinaridade: territórios e deslocamentos. São Leopoldo: UNISINOS, 2007, p. 5-7. CD-ROM.

VELLASCO, Ivan de Andrade. As seduções da ordem: violência, criminalidade e administração da justiça Minas Gerais, século 19. São Paulo: EDUSC, 2004.

Recebido em: 15/06/2017.

Revisado em: 15/10/2017. 